\title{
An Investigation of a Podcast Learning Project for Extensive Listening
}

\author{
Chun-Chun Yeh \\ National Chung Cheng University, Taiwan
}

\begin{abstract}
This paper investigates a podcast learning project integrated into an English speaking and listening class for the purpose of promoting extensive listening and fostering independent learning. The study collected data through a questionnaire, students' podcast diaries, and observation notes on student project presentations, seeking to examine students' learning experiences as well as their views of using podcasts for pedagogical purposes. Results suggested that students were strategic in choosing podcasts suitable for their interests and proficiency levels. Overall, they found learning from podcasts not only convenient but also useful in enhancing their language proficiency and world knowledge. Their general satisfaction with the experience can be attributed to factors including freedom of choice, meaningful practice, and close integration with the syllabus. However, students also experienced frustration with podcasts containing unscripted authentic content delivered at a fast speech rate.
\end{abstract}

Input is considered critical in second language learning (Zhao \& Lai, 2005). Many teachers strive to maximize target language input that suits students' proficiency levels and engages their interests. However, they cannot hope to provide sufficient input within the time constraints of the classroom. It is therefore imperative for teachers to find ways to extend learning beyond the classroom. In recent years, researchers and practitioners have started to recognize podcasting as a technological tool that can be effectively incorporated into language teaching and learning. The biggest benefit of podcasting is that it can provide an unlimited amount of authentic targetlanguage input across a wide range of subjects (Chinnery, 2006). Furthermore, it can be used on portable devices such as mp3 players to facilitate an on-demand and on-the-go learning approach (McQuillan, 2006; Stanley, 2006; Stoks, 2005). This paper describes a podcast learning $(\mathrm{PL})$ project integrated into an English speaking and listening class for the purpose of encouraging students to engage with listening materials of their own choice. The study collected data from multiple sources to examine students' learning from existing podcast resources. It also explored factors affecting students' choice of podcasts and the perceived benefits and problems of using podcasts for pedagogical purposes.

\section{Literature Review}

\section{Extensive Listening and Independent Learning}

Modeled on the extensive reading approach (Susser \& Robb, 1990), extensive listening (EL) is defined as referring to an individualized listening activity with large amounts of target language input of learners' interests and at their levels. The value of EL lies in increasing "automaticity of 
recognition of words in their spoken form, in turn leading to improved aural fluency and thus improvement in overall comprehension" (Brown, 2007, p. 15). Ridgway (2000, p. 180) also regarded automaticity as a key element in language acquisition and held that practice plays the most important role in achieving automaticity: "Practice is the most important thing. The more listening the better, and the subskills will take care of themselves as they become automatized." Renandya and Farrell (2011, p. 56) advanced a similar belief: "just like reading, listening is best learnt through listening."

Another rationale for encouraging EL is the concept of "language learning for life" (Field, 2008, p. 4). Field argued that instructors need to provide a type of learner training that "involves preparing learners so that they can take full advantage of the sources of linguistic information that the real world provides" (p. 5). In other words, this approach aims to equip learners with the ability to continue learning after they complete language courses and when the teacher is not there to assist them. In this approach, reading and listening are two natural means of extending learners' knowledge through independent learning, the latter having an extra benefit of enhancing spoken fluency (Field, 2008). In this sense, EL can be used as a means to foster independent learning, and for teachers and students seeking to take advantage of new technology, podcasts can provide the rich target language input needed in the EL approach.

\section{Podcasting in Educational Settings}

Podcasts can be understood as online "audio or video broadcasts that contain a Really Simple Syndication (RSS) feed, allowing users to 'subscribe' to the podcast" (O'Bryan \& Hegelheimer, 2007 , p. 165). Once subscribed, podcast programs can be automatically delivered to the user's computer or portable media player when new episodes are released. Using existing resources is one of the two main potential uses for podcasting described in Rosell-Aguilar's taxonomy (2007). Existing podcast resources for language learning can be further divided into two main categories. The first is content created by native speakers for the consumption of native speakers, such as news podcasts released by broadcast media. The second category is teaching content created for language learning. Rosell-Aguilar (2007) sub-classified this category into complete courses and supporting materials either for a particular audience or for independent learners. The latter subgroup of resources—supporting materials for independent learning — can arguably be most readily used by classroom teachers for providing target language input. The PL project described in this paper featured podcasts in this category.

A major consideration in using podcasting in education is that it allows flexibility. The podcasting literature has determined that time, location, and pacing as the dimensions where this flexibility can be realized (Salmon \& Nie, 2008). As a result of the time flexibility of podcasting, a learning activity is no longer constrained by time and location (Hew, 2009). Learners can access learning materials on the move, assuming they own personal mobile devices such as mobile phones and personal media players. A further advantage of podcasting is the provision of bite-sized learning opportunities (Lee \& Chan, 2007), enabling learners to take advantage of idle time for constructive learning purposes. In addition to this mobility, having the ability to replay podcasts has also been found to improve learning (Salmon \& Nie, 2008). The facility to download podcasts and listen repeatedly allows learners to work at their own pace to achieve the desired learning outcomes. These three dimensions of flexibility also contribute to learners' choice and control, which are considered key elements of learner autonomy and independent learning (Benson, 2001; Pemberton, Toogood, \& Barfield, 2009).

In recent years, podcasting has been adopted in a wide variety of educational contexts. In subject courses, podcasting is often used to deliver recorded lectures and speeches (O'Bryan \& Hegelheimer, 2007), enrich distance learning, facilitate self-paced learning, aid slower learners 
and to further develop advanced and / or highly motivated learners, among other uses (Walls et al., 2010). In language learning classrooms, podcasting has also been adopted for training in specific language skills, such as pronunciation (Ducate \& Lomicka, 2009), oral and aural skills (Abdous, Camarena, \& Facer, 2009; Chan, Chi, Chin, \& Lin, 2011) and listening strategy training (O'Bryan \& Hegelheimer, 2007). These studies however, primarily involved either teacher-created or student-produced podcasts. Although these projects have generally met with positive reactions, the resources and technologies involved may not be accessible and the time and effort invested may not be viable for all teachers. It is therefore proposed that teachers use existing resources for designing a podcast project that both engages student interest and promotes EL. This kind of project can be as simple as the podcast homework suggested by Field (2008), where the teacher selects a weekly podcast for students to download and study during the week. Students listen to the podcast as frequently as needed and provide feedback at the end of the week. For more advanced and highly motivated students, teachers can design a learner-centered podcasting project, carefully integrating in-class activities to guide and scaffold students' exploration of podcasts for language development. This study presents the implementation of such a learner-centered podcasting project and investigates students' perceptions of its advantages and problems, seeking to answer the following research questions:

1. How do EFL university students use online podcast resources for listening practice?

2. How do they perceive the use of podcasting for educational purposes?

\section{Methods}

\section{Context of the Study and Participants}

The study was conducted in an English speaking and listening course at a public university in southern Taiwan. The course was mandatory for first-year English majors and was also open to all other students on an optional basis. Among the 23 undergraduates registered for the course, 13 were English majors and 10 were non-English majors. Their estimated English competence levels ranged from low-intermediate to low-advanced. None of the students had used podcasting for English learning purposes previously.

\section{Design and Implementation of the PL Project}

This podcasting project was designed to be closely integrated with the coursework, including an orientation, student sharing of their PL experience, teacher-directed podcast sessions, diary writing, and an oral presentation on their learning outcomes. First, an orientation session was given in the beginning of the semester to demonstrate how to find and use podcasts. In Weeks 2 and 3 of the project, students were invited to share initial podcasting experiences to facilitate peer learning and identify podcasts that fit their interests and proficiency levels. Furthermore, teacher-directed podcast sessions were designed with the aim of exposing students to a wide variety of online audio resources. In these sessions, the teacher also demonstrated ancillary learning materials such as listening comprehension quizzes, transcripts, and vocabulary lists. Additionally, students were asked to keep a diary of their PL experiences (see Appendix A for the suggested format for diary entries). The diaries served the purpose of developing students' independent learning skills and facilitating the teacher's evaluation of student progress (Kemp, 2010; Yeh, 2008). Finally, at the end of the two-month project, students were asked to summarize their PL experiences and to give a five-minute oral presentation to the class about the podcast most useful to their English learning. The presentation included the podcast's basic data and an explanation of how it was used for language learning, followed by an evaluation of the overall experience. 


\section{Data Collection and Analysis}

The data collected for this study included questionnaire responses, student podcast diaries and the teacher-researcher's notes on students' PL project presentations. First, an anonymous survey was conducted at the end of the project using a four-part questionnaire (Appendix B). Part A focused on students' prior podcasting experiences and current podcasting practices. Part B, using a 4-point scale, investigated factors affecting students' podcast subscriptions. Part $C$ focused on supplementary activities that students performed to facilitate podcast listening. The final section used a 5-point Likert scale to measure students' level of agreement with eight statements concerning their PL experiences. This part also included two open questions to elicit students' perceptions of the advantages and problems of PL. Second, student diaries kept for the project were collected and prepared for analysis. Finally, the teacher-researcher's notes on students' project presentations were also used to triangulate the data. The notes included the featured podcast, reasons, and additional notes.

For data analysis, descriptive statistics were calculated on the responses to the scaled questions in the questionnaire. The responses to the open questions, together with qualitative data from podcast diaries and teacher-researcher's notes on student presentations, were read, coded, and then categorized according to the themes developed through analysis.

\section{Results}

\section{Questionnaire Findings}

Twenty-two students completed the survey. Survey findings indicated that students' podcast listening behavior varied widely (Table 1), but the majority subscribed to between 2 and 5 podcasts $(77 \%)$, listened to podcasts 2 or 3 times a week (55\%), and spent less than 30 minutes on each occasion (59\%).

\section{Table 1}

\section{Podcast Use Patterns}

\section{Subscribed podcasts}

Frequency (per week)

Time spent each listening session
$1(14 \%) ; 2-5(77 \%) ; 6-10(9 \%)$

1 (9\%); $2-3$ (55\%); $4-7$ (27\%); more than 7 (9\%)

Less than $30 \mathrm{~min}$. (59\%); $30 \mathrm{~min}-1 \mathrm{hr}(27 \%)$; more than $1 \mathrm{hr}(14 \%)$

As to the factors affecting a student's decision to subscribe to a podcast, "interest in the subject" of the podcast was found to be the most important, followed by speaking speed, content difficulty, availability of transcripts, and episode length (Table 2).

Table 2

\section{Factors Affecting Decision to Subscribe to Podcasts}

\begin{tabular}{lll}
\hline Factor & $M$ & $S D$ \\
\hline Episode length & 2.64 & 0.85 \\
Speaking speed & 3.05 & 0.84 \\
Interest in the subject & 3.23 & 0.97 \\
Content difficulty & 2.91 & 0.61 \\
Accent (American, British, or others) & 2.32 & 0.89 \\
Format (audio or video) & 2.23 & 1.11 \\
Transcript (with or without) & 2.77 & 1.15 \\
Language (English or bilingual) & 2.18 & 1.10 \\
\hline
\end{tabular}


The questionnaire also explored whether and what supplementary activities were performed during or after podcast listening. Results showed that students conducted multiple activities to facilitate learning from podcasts (Table 3), suggesting a rather serious attitude towards and heavy investment in the PL project. It can also be observed that two of the three highly frequently performed activities_consulting a dictionary ( $86 \%)$ and listening repeatedly $(82 \%)$ involved tackling immediate listening problems and seeking overall textual comprehension.

Table 3

\section{Supplementary Activities to Facilitate PL}

\begin{tabular}{lcc}
\hline Activity & Number of students & $\%$ \\
\hline Consulting a dictionary & 19 & $86 \%$ \\
Taking notes & 10 & $45 \%$ \\
Searching for supplementary information & 11 & $50 \%$ \\
Learning new words & 18 & $82 \%$ \\
Repeated listening & 18 & $82 \%$ \\
\hline
\end{tabular}

The next part of the questionnaire explored students' perceptions of the podcasting activity. With the first three items concerning the perceived benefits of podcasting, students indicated strong agreement. In particular, $95 \%$ of the students agreed that listening to podcasts enriched their world knowledge, while $86 \%$ agreed that the activity improved their English listening ability. Approximately two-thirds of the students (63\%) strongly agreed or agreed that the activity increased their English learning motivation. Items 4-6 explored the students' perceived difficulties of using podcasts for language learning. In terms of technology, approximately three-quarters of the students $(77 \%)$ found it easy to learn to use podcasts, while two students $(9 \%)$ reported some difficulty in mastering the technology. Regarding the fifth and sixth items, half of the students found it easy to locate podcasts that suited their interests, while $59 \%$ encountered minimal difficulty in finding podcasts suitable for their proficiency level; for both items, almost one-fifth of the students $(18 \%)$ indicated they found finding suitable podcasts difficult. However, the PL project was, overall, an enjoyable experience for the class $(82 \%)$. In addition, more than two-thirds of the students $(68 \%)$ indicated that they would continue to use podcasts for English learning purposes.

The questionnaire contained two open questions to encourage the students to suggest what, in their view, were the biggest strengths / limitations of using podcasts for pedagogical purposes. A summary of student comments about the advantages of podcasting is given in Table 4.

Table 4

Summary of Comments Regarding the Advantages of PL

\begin{tabular}{lcl}
\hline \multicolumn{1}{c}{ Strength } & $\begin{array}{c}\text { Number of } \\
\text { responses }\end{array}$ & \multicolumn{1}{c}{ Example comments } \\
\hline Language learning & 7 & It can improve my English listening ability. \\
Knowledge & 7 & I can get the latest information. \\
Convenience & 6 & You can listen to it whenever you want. \\
Variety & 2 & It has a variety of categories which we can choose. \\
Others & 3 & It's free. \\
\hline
\end{tabular}


While seven students referred to language improvement as a major advantage of $\mathrm{PL}$, an equal number reported that podcasts provided opportunities to learn ideas, new information, and world news. Convenience was also viewed by six students as a big advantage of PL. They praised podcasts for easy access and automatic updates. They could download and listen to podcasts "at any time" (S2), so PL was "not limited by time and place" (S6). In addition, two students appreciated the variety afforded in the podcast world. One explained that "I can try to find one that suit my interest. I will not bored when listening to them" (S8).

Finally, the students also named problems they had encountered in PL, which can be generalized into three categories: language, technology, and personal (See Table 5).

\section{Table 5}

\section{Summary of Comments Regarding the Problems of PL}

\begin{tabular}{lcl}
\hline Problem & $\begin{array}{c}\text { Number of } \\
\text { responses }\end{array}$ & \multicolumn{1}{c}{ Example comments } \\
\hline Language & 6 & $\begin{array}{l}\text { Speed of talking is fast. } \\
\text { Bechnology }\end{array}$ \\
$\begin{array}{lcl}\text { Because I don't have iPod, I can only listen those podcast } \\
\text { programs through my computer. }\end{array}$ \\
$\begin{array}{l}\text { Personal } \\
\text { Sometimes I just don't want to listen to it. }\end{array}$
\end{tabular}

The students encountered language problems, including rapid speech, lack of understanding, and lack of transcripts. In particular, several students reported feeling frustrated when they could not understand the content even after repeated listening. Six students complained about various technology problems, caused mainly because they did not own iPods and had to spend long periods in front of their desktops for podcast listening. The five comments in the Personal category were more varied. One student had difficulty finding suitable podcasts. Another seemed to be overwhelmed by the amount of accumulated content from podcasts with daily updates and another mentioned the lack of interaction.

\section{Observations From Student Presentations and Podcast Diaries}

Analysis of student presentations and podcast diaries provided further information about students' learning strategies and experiences. It was found that among the most useful podcasts named in the project presentations (see Appendix C for a list of student-selected podcasts), podcasts targeted at ESL learners were chosen the most frequently $(n=9)$. An equal number of students chose to feature news podcasts, while a further three chose education podcasts such as TED Talks. The students provided reasons for their podcast choices, including the podcasts came with transcripts, were of short duration, had speakers with a British accent, were interesting, were not too difficult and were recommended by the teacher. Several generalizations can be made from the students' choice of podcasts. First, textual support was apparently very important to these intermediate English learners. In fact, of all the participating students, only three chose podcasts that did not include episode transcripts. Second, the students were observed to be careful and strategic in managing this PL project. In addition to finding podcasts covering interesting topics, they took care to choose podcasts of short duration (typically five to six minutes per episode) and of moderate difficulty (at a reduced speech rate or of bilingual instruction in English and the students' mother tongue, Chinese). Many also seemed to depend on teacher recommendations. More than half of their favorite podcasts were featured in the teacher-directed podcast sessions. Finally, half of the students chose podcasts delivered in British English accents. Although this may in part reflect the teacher's recommendations, some of the students explained that their choice was motivated by their 
curiosity about British accents (as contrasted with American English, normally adopted as the model for English learning in Taiwan), indicating that podcasts can indeed provide opportunities for explorations of a wide range of not just topics and interest areas, but accents and linguistic differences as well.

Finally, observations from student diaries revealed their exploration process in the podcast world. In the beginning, they had to navigate through this unfamiliar technology and explore what it had in store for them. Several students reported experiencing a period of difficulty before finding a perfect fit for their interests and language levels. However, the diaries revealed that most of the students sought to assess podcasts according to their own criteria so as to find a podcast neither too challenging nor too easy for their language levels, as shown in the following excerpts (unedited):

Sometime I try to "BBC discovery" but it is nearly half hours and some speakers speak too fast. After listen two times, I give up.

I change my mind to switch VOA [Special English] to this program because the special English is really slow and sometimes I felt bored.

I found that I can almost understand what the hosts are talking about. Next time I will pick some more challenging podcasts to enhance my listening ability.

The students explored not only available podcast selections but also the tool's capabilities. For example, one reported his attempt at taking advantage of the mobility afforded in PL, although with a less than satisfactory result:

Because I have to go back to my hometown with my family and sweep the forefathers' grave, I just download the MP3 into my cell phone that I can listen to it when I am in car. . . . however, I was attacked by my little brother who try to interrupted me in the car. Furthermore, because of the car swaying and the boring long trip, sometimes I can't focus on. Finally, I consider that I still prefer staying before computer much than listening by cell phone.

Despite the various challenges, the students generally seemed to enjoy learning from podcasts. One student commented in the diary that the project felt "less like an assignment." Another left a note in the questionnaire to express her appreciation of the experience:

Roughly speaking, it's a wonderful experience of listening to podcast. I think I will use my free time to listen it and keep finding interesting podcast!!

\section{Discussion}

In terms of student satisfaction, the self-reported data collected in the present study revealed that, overall, the PL project was successful. This success may be attributed to three factors: freedom of choice, meaningful practice, and close integration with the syllabus. First, the students were given complete freedom to choose the podcasts to subscribe to, the number of episodes to listen to, and the amount of time to spend on listening. In line with research on free voluntary reading (Judge, 2011; Susser \& Robb, 1990), this freedom of choice should contribute to the students' overall satisfaction with the experience. Furthermore, with the freedom of podcast choice, the students were given opportunities to do meaningful practice instead of mere mechanical drills. In addition to learning to listen, they listened to learn more about their areas of interest, assisted by a wide range of available podcasts. Such meaningful practice is 
widely recognized to be engaging for learners and indispensable in second language acquisition (Renandya \& Farrell, 2011; Rosell-Aguilar, 2007). Finally, as described in the Methods section, this PL project was designed to integrate closely with the speaking and listening course through measures including introductory orientation, in-class podcast sessions, constant reminders from the instructor, peer experience sharing, podcast diaries, and project presentations. All these activities served to guide students through the process of learning to use podcasts and help them recognize podcasting as a useful educational tool. Such teacher guidance and careful integration with the syllabus have been identified as contributing to effective podcasting use for learning purposes (Abdous et al., 2009; Chan et al., 2011; Copley, 2007; O'Bryan \& Hegelheimer, 2007).

Although generally satisfied, the students encountered some difficulties and frustrations during the learning process. In particular, they seemed to experience considerable frustration with podcasts delivered at a rapid speech rate. These podcasts tended to contain unscripted authentic content created for native speaker audiences. This problem with authentic texts has been recognized in the literature on listening instruction (Hinkel, 2006; Vandergrift, 2004). To help alleviate the problem, teachers can consider learner training in metacognitive strategies (Cross, 2011; Goh, 2008; Vandergrift, 2007). Several commonly taught strategies include activating background knowledge about the topic, anticipating the language that might occur in the text, writing down a word to check its meaning later, and note-taking. Alternatively, a more structured approach to podcast listening, as detailed in a later section, can be adopted.

Regarding the concept of flexibility, this study found that PL may allow learners more flexibility in time and pacing, but not in place. This relative lack of mobility in place may be accounted for by two factors: (a) mobile device ownership and technical capabilities and (b) study habits and purpose. Although this study did not survey mobile device ownership, the students' complaints about having to sit for long periods in front of computers suggested that they either did not have handheld devices enabling mobile learning or they were not familiar with the technicalities of transferring audio files to their mobile devices. This corroborates findings in previous research showing the impact of technical capabilities on podcasting use (Abdous et al., 2009). Furthermore, students may need a quiet place for podcast listening, particularly when English is not their first language and when they see podcast listening as a serious learning task requiring concentration. In addition, listening to podcasts on the move makes it difficult to perform supplementary learning activities such as taking notes and consulting dictionaries, which the students reported performing with high frequency.

\section{Pedagogical Suggestions}

For teachers who wish to use existing podcast resources, several suggestions are offered. Teachers should first familiarize themselves with the technology and available resources in order to introduce learners to the basics of podcasting. Furthermore, while giving learners freedom to explore the podcast world on their own, teachers should emphasize the varying quality of existing podcast resources. They can also help develop learners' online information literacy skills by demonstrating how to evaluate podcasts using cues such as descriptions and customer reviews (Rosell-Aguilar, 2007). Furthermore, this paper contends that integration with the syllabus is key to ensuring the success of a PL project. Therefore, teachers should consider how they can organize the course schedule and assignments to guide learners through the learning process. One option is to adopt a project-based model as featured in this study to motivate learners, encourage student ownership in the learning process, and facilitate peer sharing and continuous reflection upon the experience (Stoller, 2006). With lower-level students, teachers may consider adopting a more structured approach, particularly in the beginning stage of the project. For example, teachers can assign a podcast for the whole class 
to download and listen to. They can also demonstrate how to use ancillary materials such as episode transcripts, if available, to enhance learning outcomes. Once students become more familiar with the technology and its potential uses, they can be encouraged to explore and expand their listening repertoires.

\section{Limitations and Conclusion}

The present study does have limitations, perhaps the major one being a reliance on selfreported data. It should also be noted that variables such as learners' English proficiency and technical capabilities cannot be controlled, but it is likely that individual students approached podcasting differently depending on factors such as areas of study, personal interests, language competence and English learning motivation. While this study has identified general usage patterns and perceptions of podcasting among EFL university students, case studies would further advance understanding of individual strategy use in learning from podcasts.

The amount of exposure to target language input is generally recognized as an important predictor of language achievement levels. Using podcasts as EL material involves only minimal technological knowledge, but it can provide a motivating variety of resources and facilitate learners' engagement with listening materials at a time and place convenient to them. It is hoped that this study will stimulate additional consideration of the use of podcasts in listening instruction and aid students in leveraging this technology for second language acquisition.

\section{Author Note}

Chun-Chun Yeh, Department of Foreign Languages and Literature, National Chung Cheng University, Taiwan.

Correspondence concerning this article should be addressed to Chun-Chun Yeh, Department of Foreign Languages and Literature, National Chung Cheng University, No. 168, University Rd., Min-Hsiung, Chia-Yi 621, Taiwan. E-mail: folccy@ccu.edu.tw 


\section{References}

Abdous, M., Camarena, M. M., \& Facer, B. R. (2009). MALL technology: Use of academic podcasting in the foreign language classroom. ReCALL, 21(1), 76-95.

http://dx.doi.org/10.1017/S0958344009000020

Benson, P. (2001). Teaching and researching autonomy in language learning. Harlow, UK: Pearson.

Brown, R. (2007). Extensive listening in English as a foreign language. The Language Teacher, 37(12), 15-19.

Chan, W. M., Chi, S. W., Chin, K. N., \& Lin, C. Y. (2011). Students' perceptions of and attitudes towards podcast-based learning-A comparison of two language podcast projects. Electronic Journal of Foreign Language Teaching, 8, 312-335. Retrieved from http://eflt.nus.edu.sg/archive/v8s12011.htm

Chinnery, G. M. (2006). Going to the MALL: Mobile assisted language learning. Language Learning \& Technology, 10(1), 9-16.

Copley, J. (2007). Audio and video podcasts of lectures for campus-based students: Production and evaluation of student use. Innovations in Education and Teaching International, 44(4), 387-399. http://dx.doi.org/10.1080/14703290701602805

Cross, J. (2011). Metacognitive instruction for helping less-skilled listeners. ELT Journal, 65(4), 408-416. http://dx.doi.org/10.1093/elt/ccq073

Ducate, L., \& Lomicka, L. (2009). Podcasting: An effective tool for honing language students' pronunciation? Language Learning \& Technology, 13(3), 66-86.

Field, J. (2008). Listening in the language classroom. Cambridge, England: Cambridge University Press. http://dx.doi.org/10.1017/CBO9780511575945

Goh, C. (2008). Metacognitive instruction for second language listening development: Theory, practice and research implications. RELC Journal, 39(2), 188-213. http://dx.doi.org/10.1177/0033688208092184

Hew, K. (2009). Use of audio podcast in K-12 and higher education: A review of research topics and methodologies. Educational Technology Research and Development, 573), 333-357. http://dx.doi.org/10.1007/s11423-008-9108-3

Hinkel, E. (2006). Current perspectives on teaching the four skills. TESOL Quarterly, 4O(1), 109131. http://dx.doi.org/10.2307/40264513

Judge, P. B. (2011). Driven to read: Enthusiastic readers in a Japanese high school's extensive reading program. Reading in a Foreign Language, 23(2), 161-186.

Kemp, J. (2010). The listening log: Motivating autonomous learning. ELT Journal, 64(4), 385395. http://dx.doi.org/10.1093/elt/ccp099

Lee, M. J. W., \& Chan, A. (2007). Pervasive, lifestyle-integrated mobile learning for distance learners: An analysis and unexpected results from a podcasting study. Open Learning, 22(3), 201-218. http://dx.doi.org/10.1080/02680510701619810

McQuillan, J. (2006). Language on the go: Tuning in to podcasting. International Journal of Foreign Language Teaching, 2(1), 16-18.

O'Bryan, A., \& Hegelheimer, V. (2007). Integrating CALL into the classroom: The role of podcasting in an ESL listening strategies course. ReCALL, 19(2), 162-180. http://dx.doi.org/10.1017/S0958344007000523

Pemberton, R., Toogood, S., \& Barfield, A. (Eds.). (2009). Maintaining control: Autonomy and language learning. Hong Kong: Hong Kong University Press. http://dx.doi.org/10.5790/hongkong/9789622099234.001.0001

Renandya, W. A., \& Farrell, T. S. C. (2011). 'Teacher, the tape is too fast!' Extensive listening in ELT. ELT Journal, 65(1), 52-59. http://dx.doi.org/10.1093/elt/ccq015

Ridgway, T. (2000). Listening strategies-I beg your pardon? ELT Journal, 54(2), 179-185. http://dx.doi.org/10.1093/elt/54.2.179 
Rosell-Aguilar, F. (2007). Top of the pods -in search of a podcasting "podagogy" for language learning. Computer Assisted Language Learning, 20(5), 471-492. http://dx.doi.org/10.1080/09588220701746047

Salmon, G., \& Nie, M. (2008). Doubling the life of iPods. In G. Salmon \& P. Edirisingha (Eds.), Podcasting for learning in universities (pp. 1-11). Maidenhead, UK: Open University Press.

Stanley, G. (2006). Podcasting: Audio on the internet comes of age. TESL-EJ, 9(4), 1-7.

Stoks, G. (2005). Podcasts: New materials for teaching listening comprehension. Babylonia: The Journal of Language Teaching and Learning, 2005(N4), 46-47. Available at http://babylonia.ch/fileadmin/user_upload/documents/2005-4/podcast.pdf

Stoller, F. (2006). Establishing a theoretical foundation for project-based learning in second and foreign language contexts. In G. H. Beckett \& P. C. Miller (Eds.), Project-based second and foreign language education: Past, present, and future (pp. 19-40). Greenwich, CT: Information Age.

Susser, B., \& Robb, T. N. (1990). EFL extensive reading instruction: Research and procedure. JALT Journal, 12(2), 161-185.

Vandergrift, L. (2004). Listening to learn or learning to listen? Annual Review of Applied Linguistics, 24, 3-25. http://dx.doi.org/10.1017/S0267190504000017

Vandergrift, L. (2007). Recent developments in second and foreign language listening comprehension research. Language Teaching, 40(3), 191-210. http://dx.doi.org/10.1017/S0261444807004338

Walls, S. M., Kucsera, J. V., Walker, J. D., Acee, T. W., McVaugh, N. K., \& Robinson, D. H. (2010). Podcasting in education: Are students as ready and eager as we think they are? Computers \& Education, 54(2), 371-378. http://dx.doi.org/10.1016/j.compedu.2009.08.018

Yeh, C.-C. (2008). Promoting autonomy through listening journals. The East Asian Learner, 4(2), 14-23.

Zhao, Y., \& Lai, C. (2005). Technology and second language learning: Promises and problems. In L. L. Parker (Ed.), Technology-based learning environments for young English learners: Connections in and out of school (pp. 167-207). Mahwah, NJ: Lawrence Erlbaum. 


\section{Appendix A}

\section{Suggested Format of Podcast Diary Entry}

Name of the podcast:

Duration: minutes per episode

Frequency: Daily? Weekly?

Language: English? Bilingual (English plus Chinese)?

Category: Education? Music? News? Others?

Difficulty: Easy? Medium? Challenging?

This week's podcasting experience (50-200 words): 


\section{Appendix B \\ Questionnaire on Podcast Learning}

\section{Part A: Prior Experiences and Current Practices}

1. Is this the first time you use podcasting for English learning purposes?

$\square$ Yes $\quad \square$ No. I used it for English learning purposes before this class.

2. How many podcasts are you currently a subscriber to?
$\square$ Only 1
$\square 2-5$
$\square$ 6-10
$\square 11-20$
$\square$ more than 20

3. During this podcasting project, how often do you listen to podcasts? time(s) a week

4. In average, how much time do you spend each time you listen to podcasts? (hours or minutes)

\section{Part B: Factors in Choosing a Podcast}

How important are the following factors in your choosing a podcast to subscribe to?

\begin{tabular}{|l|l|l|l|l|}
\hline Factor & $\begin{array}{c}\text { Not at all } \\
\text { important }\end{array}$ & $\begin{array}{c}\text { Slightly } \\
\text { important }\end{array}$ & Fairly important & Very important \\
\hline Length of each episode & & & & \\
\hline Speaking speed & & & & \\
\hline Interest in the subject & & & & \\
\hline Content difficulty & & & & \\
\hline $\begin{array}{l}\text { Accent (e.g., American, British, } \\
\text { or others) }\end{array}$ & & & & \\
\hline Format (audio or video) & & & & \\
\hline Transcript (with or without) & & & & \\
\hline $\begin{array}{l}\text { Language (e.g., English or } \\
\text { bilingual) }\end{array}$ & & & & \\
\hline
\end{tabular}

\section{Part C: Podcast Learning Activities}

What learning activities do you do when (or after) listening to podcasts? Check all that apply.

$\square$ Consulting a dictionary

$\square$ Taking notes

$\square$ Searching for supplementary information online

$\square$ Learning new words

$\square$ Repeated listening

$\square$ None of the above

$\square$ Others, please describe: 


\section{Part D: Podcast Learning Experiences}

Please indicate $(\checkmark)$ whether you agree or disagree with the following statements.

\begin{tabular}{|c|c|c|c|c|c|}
\hline Item & $\begin{array}{c}\text { Strongly } \\
\text { agree }\end{array}$ & Agree & Not sure & Disagree & $\begin{array}{l}\text { Strongly } \\
\text { disagree }\end{array}$ \\
\hline $\begin{array}{l}\text { 1. Listening to podcasts improves my English } \\
\text { listening ability. }\end{array}$ & & & & & \\
\hline $\begin{array}{l}\text { 2. Listening to podcasts increases my English } \\
\text { learning motivation. }\end{array}$ & & & & & \\
\hline $\begin{array}{l}\text { 3. Listening to podcasts enriches my world } \\
\text { knowledge. }\end{array}$ & & & & & \\
\hline $\begin{array}{l}\text { 4. It is easy for me to learn the technology for } \\
\text { using podcasting. }\end{array}$ & & & & & \\
\hline $\begin{array}{l}\text { 5. It is easy for me to find podcasts that suit } \\
\text { my interest. }\end{array}$ & & & & & \\
\hline $\begin{array}{l}\text { 6. It is easy for me to find podcasts that suit } \\
\text { my level. }\end{array}$ & & & & & \\
\hline $\begin{array}{l}\text { 7. Listening to podcasts is an enjoyable } \\
\text { experience. }\end{array}$ & & & & & \\
\hline $\begin{array}{l}\text { 8. I will continue to use podcasting for English } \\
\text { learning purposes. }\end{array}$ & & & & & \\
\hline
\end{tabular}

9. What was the best thing about or biggest strength of podcasting as a learning resource?

10. What was the worst thing about or biggest limitation of podcasting as a learning resource? 


\section{Appendix C \\ Podcasts Featured in Students' Project Presentations}

- BBC 6 Minute English, available at http://www.bbc.co.uk/podcasts/series/6min

- BBC Learning English for China, available at http://www.bbc.co.uk/podcasts/series/aab

- CNN Student News, available at http://rss.cnn.com/services/podcasting/studentnews/rss.xml

- English as a Second Language Podcast, available at http://www.eslpod.com/website/index_new.html

- Poem of the Day, available at http://www.poetryfoundation.org/features/audio?show=Poem\%20of\%20the\%20Day

- TED Talks (video), available at http://feeds.feedburner.com/tedtalks_video

- VOA Words and Their Stories, available at http://learningenglish.voanews.com/archive/learningenglish-programs-radio-wordsstories/latest/978/987.html 